\title{
Media Effects on Children's Social and Moral Development: A Theological Moral Study in Africa
}

\author{
Jacob Nwannabuike Anioke \\ Catholic Institute of West Africa, Rivers State, Nigeria
}

\begin{abstract}
In this 21 st century, whether we like it or not, it is very clear that the Internet, social media, and all ad of the related technology have come to stay. This new technological discovery has brought great and wonderful benefits to our family's lives and relationships. However as it is always the case with any new innovations, it has its own negative side. This paper aims at investigating what actually social media is and how it translates to children, especially African children, as it relates to family and social living. Actually Internet provide benefits in areas such as cognitive and social development, it also presents risks together with opportunities for children's growth and development. It is common today to see children spending great quality of their time using other social websites. It is also evidenced that Internet provide benefits in the area of emotional and intellectual development and at the same time present risk as well as opportunities to children's development in functional and societal challenges. Therefore social media gives the children of the present age the opportunity to enter into global entertainment and communication. As a result of this development, there is now Internet addiction of children. Hence, there is serious need for parents to be aware of the nature of social media sites, their children are using. This is because not all of them are healthy environments for children. Experts such as childhood educators and psychologist even Paediatricians are equipped and so are better hands to assist parents not only to know and understand these websites but to encourage proper use and make them to monitor for potential problems such as cyber-bullying, facebook depression, exposure to inappropriate content and sexting. This paper proffers some recommendation that certainly will assist parents to bring up their children up to be vibrant adult even in this technological era.
\end{abstract}

Keywords: media effects, Internet, children, social and moral development, Africa

\section{Introduction}

We do not need prophets nor seers to tell us that social media is here with us; and that it is impossible to reject and hide from this new form of media. It is an essential part of socialization among peer groups. It is also used to market and motivate people to become part and parcel of a large community. The impart of the new form of media is seen in every aspect of human life. It is fast changing the way people communicate, find and share information. Most social media offer communication through the use of facebook, myspace, Twitter, Youtube, Tango, Instagram, Telegram, Wechat and many others. New applications on smart-phones for photography and video made digital pave way for media to be created, edited and shared quickly. Once it is in this new digital cloud, it can be viewed or used by anyone. It is no longer yours alone. These new advances in technology provide avenues for people to share things about themselves to the world to view. Now children and

Jacob Nwannabuike Anioke, Rev. Fr., Ph.D., Lecturer, Moral Theology Department, Catholic Institute of West Africa. 
adolescence have practically new ways to access communication and entertainment, and you know what? The long-term effects of these new advances in technology are still unknown.

Many parents and experts now worry about how exposure to technology might affect children developmentally. Actually social media like facebook and MySpace offers opportunities for connecting with friends, classmates and people with shared interest. It is on record that the numbers of children using such social media have increased drastically. Florence Undiyaundeye (2014) maintains that a large number of this generation's social emotional development is occurring on Internet and cell phones. Children learn by observation and imitation. Simply put, your child will imitate what he/she sees and what others do around him or her. This is so because they are not yet mature enough to separate good from bad. Hence, the need for close observation to assist them to grow to maturity. Florence Undiyaundeye opines: "Internet can be a positive influence on children if parents and other adults get involve when children get access. But it can be hard to pick the good from the bad when it comes to media. There are many negative messages about media and how viewing and interacting with it harm the child. Children can also benefit from media depending on the child's age, kind and quality of the media in use. Going further, she says "adolescence is a period a transition between childhood and adulthood whereby identity formation, peer relationship, sexuality and self-worthy are exploited. Today for adolescents, the Internet is acting as a new social environment where their issues are being exploited!".

In this situation, African child is morally affected. This is because majority of the parents find it difficult to relate to their digitally enlightened children online for so many reasons. Such parents lack a basic understating of these new forms of socialization which are integral to their children's lives. They do not have the technical abilities to keep pace with their children in the social media and Internet world. This paper is set to describe some recent findings that are worth considering as you increasingly expose your children to different types/kinds of technology.

\section{Social Media and African Child}

In Africa, more than eighty percent of our children are spending a large amount of time surfing on the Internet. This is because Internet was introduced to them at a very young age into their lives. Imagine a child of six years possessing an ipad/iphone with all the Internet applications given to him by the parents. Parents to prove their love for their children go out of their way to buy expensive phones with Internet facilities and some with two Sim cards. Imagine a child in primary five owning a sophisticate phone. They spend over eight hours daily on the social media. No more time for their assignments given to them in the school. In fact, it is the parents who are doing the assignment for them while the children are busy on social media browsing. They are teachers to their parents on the use of phones. There is no application and stations on the Television that they do not know, and the hours they operate. In this case who is in charge, the parents or children? The social media have affected the African child's academic life. They are no longer developing intellectually. They do not study in school. They hope that everything is there on the Internet for them to just download, copy and paste. They go into examinations with their phones and Ipads where they downloaded the answers to the questions. This is the case both in the Primary, Secondary and University levels. Should the teacher(s) stop them from using it, they will not only fail the examination but the Teacher(s) in question should be prepared to face serious punishment from the student(s) outside the school premises which most times involves the parents. 
The social media have made African children to know little or nothing about African values. The ethics of life have being thrown into oblivion. The contents of the majority of the website are seriously detrimental to the development of the African child. The parents are not literate enough to assist them to separate the wheat from the weed, and the result is that they swallow everything on the Internet.

Watching the African Magic Movies Stations and other stations, what lessons does the African child learns from it; except how to be wicked, to steal, to kill, to form clique and gangs, how to use charms to get whatever they want and to become rich without job.

One notices today a notorious programme that is going on now called "Big Brother Naija (BBN)". We were informed that the winner of this notorious show is expected to walk away with a sum of Twenty-five million Naira and a breath taking car. What is required to win this show is nothing but to live with a bunch of fellows crazy, irresponsible people, do all sorts of immoral things, then you are the winner. Then the winner becomes a celebrity, winning big advertisements contracts, becoming the face of multinational companies. No one is thinking of an educational version of it, where some intelligent people in like manners and make then compete for similar prize. No! no one is ready to encourage sanity. In fact social media have plunged Africa society to promote evil over good, indecency over decency, immorality over morality and ungodliness over godliness. In mathematics competitions, the best candidate will go home with either a carton of indomie noodles or a carton of Peak milk or Cowbell with stipends of at most between five hundred thousand to one million naira. Yet these individuals in Big Brother Naija (BBN) will be earning millions of naira for coming to speak thrash and display nudity. And this is where our rich individual, companies and corporate organizations spend huge sums of money. Sponsoring dirty shows that contribute little or nothing to the moral and intellectual development of African Children. What a wasted generation, under the control of the devil.

If African people continue in this way, how do we raise, nurture and produce the next Chike obi, Chinua Achebe, Wole Soyinka, Cyril Stovers, Julius Nyareres; and the academia we have today that are aging out. Africa is broke morally and financially, yet the sponsors are wasting millions of Naira on such a highly immoral programme that has no good lessons for our children. Reacting to this situation, Rachel Ehmke observes that experts worry that the social media and text messages that have been once so integral to teenage life are promoting anxiety and lowering self Esteem. African children should be protected from the negative effects of this new technological advance before it is too late.

Traditionally African Children were trained to exhibit all African Social and moral values. They have respect for the elders, they value human life, and they are hard work. Among them one sees children who are self-discipline, have integrity, cherish solidarity hardworking. Today they expect adults to greet them. If you happen to meet them at any narrow entrance, oh you have to stop and let them pass first. They mock the elderly one, and have no regard for the sick. They disrespect the human life. Little wonder they only kill human being, like chickens because they have no sense of the sacred any more.

\section{Kohlberg and Moral Maturity}

Connecting media and morality is almost taken for granted. Take for instance Plato banished all storytellers from his imagined Republic save those whose tales were "in accordance with the pattern we laid down when we first undertook the education of our soldiers". The reason behind this is because listeners or viewers would admire and imitate characters of bad behaviour Matthew John Submits that Later thinkers have for the most part, agreed with Plato, as the moral panics that have greeted new media over the centuries, from 
novels to comic books to video games, can attest; as well as ongoing concern about the possible negative moral effects of media. It is also observed that a lay tradition of works were created specifically to teach the morals that are considered to be desirable; and a lot of research done on how media exposure affects specific behaviours, relatively little has focused on how it influences our judgement of right and wrong.

Lawrence Kohlberg Studied how children develop moral reasoning. Kohlberg identified six stages of moral development, two stages occurring at three distinct levels, namely, the pre-conventional, the conventional and the Post-conventional. Ronald Duska and Mariellen Whelan (1975) in their book: Moral Development, A guide to Piaget and Kohlberg referring to Pre-conventional level observed that "at this level the child is responsive to cultural rules and labels of good and bad, right or wrong, but interprets these labels in terms of either the physical or the domestic consequences of action (Punishment, reward, exchange of favours) or in terms of physical power of those who enunciate the rules and labels" (p. 45). This level has two stages under it. First stage is the instrumental relativist orientation, or the desire to obtain rewards.

Ronald Duska and Mariellen Whelan say that at conventional level, maintaining the expectations of the individual's family, group, or nations is perceived as valuable in its own rights, regardless of immediate and obvious consequences. The attitude is not only one of conformity to personal expectations and social order, but of loyalty to it, of actively maintaining, supporting, and justifying the order and identifying with the person or group involved in it. The conventional level also has two stages: First state is the interpersonal concordance of "Good Boy-nice girl" orientation, or a wish to fit in and conform in order, please others. The second is the law and order orientation or duty to fellow rules, laws and social codes (p. 46).

The third level is the Post-Conventional, Autonomous, or Principled level. For Ronald and Mariellen, at this level there is a clear effort to define moral values and principles which have validity and application apart from the authority of the group or persons holding these principles and apart from the individual own identifications with these group. It also has two stages: First stages is the social-contract legalistic orientation, or the sense of participating in a social contract. Second stage is the universal ethical principle orientation or a morality that looks to universal ethical principles of justice and the equality and dignity of all people (pp. 46-47).

Matthew Johns observes that the stages four, five and six are best illustrated by looking at how each views laws: to stage four, a law is an absolute that must be obeyed in all circumstances. To stage five, a law is seen as an expression of the will of the people, and may be altered if enough group agree to it; to stage six laws are only to be obeyed if they are seen as being just in the light of universal ethical principles. In these three stages of moral reasoning, people might react to laws discriminate against Africans by saying: "It is the Law, so follow it" or "follow the law until we change it" and "disobey an unjust law" respectively.

In this progression there are about three essential things to be noted. First, the stages describe a way of coming to a decision about moral issue, second not all people will necessary reach all the six stages. Third, children cannot be taught to behave morally through character education", though they can be taught to express particular opinion on morality, moral education has been shown to have no effect on actual behaviour, Four, finally certain thing may cause moral development to be arrested - in particular exposure to violence, children who are victims of this hardly progressed beyond stages one and two.

The question is, if exposure to real life violence can prevent youth from progressing in their moral development, can exposure to media violence have the same effect? The short answer may be "probably no". This so because we need to first find out why the youth were not progressing to stage III and beyond. May be 
because they were affected physically by the constant strive of their environment (especially those who has been found victims of or witness to domestic violence. Again may be they have learned from their peers to base their moral reasoning on "vendetta mentality". In the case, they had progressed to stage three and were conforming to a society whose values expressed stages one or two morality. In these cases, exposure to media violence, no matter how frequent or graphic is unlikely to have similar effects.

However, this does not mean that media exposure cannot influence our moral development either in positive and negative ways. It is obvious that all our moral behaviour is learned. Again much of all know about the world is learnt through media. We learn what kind of behaviour is punished (Stage 1) or what kind is rewarded (Stage 2), we learn values of our society (Stage 3). Also we learn social codes as expected for gender behaviour (stage 4) etc. In our contemporary society the Internet is seriously acting as a new social environment where children's issues are being exploited. It is very clear that in situation like transformation it is actually taking place with particular reference to how phase children communication, how they establish and maintain relationship and also how they find social support. Children learn from modelling their behaviour and imitation. They imitate what they see and what others do around them. Hence interaction online greatly shape children's offline way of living.

\section{Dark of Social Media on African Child}

In Africa very few parents are paying attention to how children's use of technology is affecting them. The Governments in place are not even interested. However, whether we know it or not, it is obvious, that the use of social media has become a risk to our children. The risks are the dark side of the social media. These can be categorized into peer to peer group; inappropriate content, lack of understanding of on-line-privacy issues. Florence Undiyaundeye organized these dark sides of social media into five. We shall now look at them briefly.

(1) Cyberbullying and online harassment: This is a process of using digital media to communicate false, embarrassing or hostile information about another person. This is the most common online risk for all children and it is a peer to peer risk. Online harassment is used often interchangeably with the term "Cyberbullying". Cyberbullying is also very common and can cause profound psychological outcomes such depression. Anxiety, sever isolation and tragically suicide.

(2) Sexting: This is a sending recording or forwarding sexually explicit message, photographs or images through cell phone, computer or other digital devices. These are distributed through cell phone or the Internet. Some teens who have engaged in sexting have been threatened or charged with felony child pornography charges.

(3) Facebook Depression: There is no doubt that facebook is one of the most powerful forms of media for communication today. Over a billion users chat, share photos and keep their families and friendship to date regularly. Scholars maintain that excessive chatting on facebook is in danger of a new phenomenon called "facebook depression". This develops when pre-teens and teens spend a great deal of time on social media sites like Facebook and then begin to show "classic symptoms of depression". They maintain that intensity of the online world is that to be a factor that may trigger depression in some adolescents. As with offline depression, preadolescents and adolescents who suffer from Facebook depression are at risk for social isolation and sometime turn too risky Internet sites and blogs for "help". This may give rise to substance abuse, unsafe sexual practices or oppressive or self destructive behavior. 
(4) Defective social relationship: spending countless hours on the Internet, children have little or no time for the family and actual friends. This weakens the family bond and limit interaction with actual people. These children miss out on real life interaction with different relatives. This results in distorted social skills and also limited real life social network leading to social isolation. Scholars are of the view that adolescents who do not have close friendships constantly have lower level of self-esteem and psychological symptoms of maladjustment. When people have more social contacts they are happier and healthier both physically and mentally.

(5) Distorted senescence of reality: obviously about half of the children between the age of 13-18 often communicate through Internet with someone they have never met in person; and about one third have seen themselves face to face (Pelliklaus foundation, 2006), some of the them endangered their lives in this practice. Some have been reported raped, killed and some were stranded to death. Many social media sites displace multiple advertisements such as banner ads, behavior ads that their web browsing behavior and demographic based ads that target people on the basic of a specific factor like age, gender, education, marital status etc. this influences children and especially their view of what is normal.

\section{Benefits of Social Media for Children}

Actually social media effects on children are not all bad. This paper agree with Florence Undiyaundeye that social media sites allow children to accomplish certain tasks that are considered important to them like staying connected with friends and family, making new friends and sharing pictures and exchanging ideas. Also social media participation offer them deeper benefits that extend into their view of self, community and world. This will become more beneficial if adults get involved with children and guide in the use of media through the visit to quality of websites by engaging the use of educational software and view of TV shows that offer extra learning opportunities. Media benefit the individual at various ages in life passage. For younger children, development benefits of media are as follows:

- Literacy skill - it helps them in learning letters of alphabets through such play school or educational computer games sesame.

- Social skill: they learn the operations of TV programmers and using computer games and websites like $\mathrm{ABC}$ for kids that show cooperative and help them to connect with others on social networking sites, by so doing, Children can develop their skill.

- Intellectual benefits like developing problem-solving and critical thinking as well as paying more attention to developing morals by comparing family value with those found in Africa and documentary content.

- Creative benefits - it helps children in imagination, art and modeling, music and media through the use of software to create a picture or being inspired to make something by a TV show.

- Political and social awareness by watching news, current affairs and documentaries.

- Value through observing good role models in the media.

- Children's motives: Christian use media for entertainment and relaxation purposes that is to relieve boredom, to play games or for social interaction and build identity.

The adolescents also use it for social interaction, social identity, peer interactions status boost and symbol, communication like email or chat, Face book, Twitter as they mature, they begin to use Internet for global contact towards career, business networking etc. Social media also increase reading, writing, and critical thinking skills through using blogs, chat room and help them, to becoming involved in message boards such as movie and news site. 


\section{Theological Moral Evaluation}

The Biblical perspectives on Child Development fall back on the most ancient source of wisdom about child development, which based child rearing, educational or social policies on time-tasted and authenticated values for the benefit and well-being of the child. Scholars maintain that from the time Abraham and Sarah, a bond has united all Jewish parents in all four corners of the earth in every generation. This bond, they force that binds the major elements of Judaism together had contributed to Jewish survival despite a history of exile, trauma and oppression.

Scholars summarizing all that has been said on the Jewish mother, Jewish family and Jewish father, defined Jewish perspective on child development with one word: Commitment - a deeply rooted, unequivocal, imprinted commitment to Children (whether one's own or those in the community and nation). The Jewish value of child-rearing is based on the development of the child as a living vehicle for the continuation of the Biblical heritage.

In any society, the concept of childhood is shaped by three major factors:

(1) The cultural ideology pertaining to children;

(2) Attitudes concerning the child as an object of parental affection;

(3) The child as an object of formal study.

Proper understanding of the Biblical perspective on Child rearing and child development is based on these three major factors. In Judaism, according to Shoshana Matznek-Bekerman ${ }^{1}$, Childhood is considered a period of purity, joy and beauty to be valued and cherished. The Talmud states "Childhood is a garland of roses" (Babylonian Talmud, Shabbat 152,119a). It is a symbol of creation, a time when the development of the human being is in its most stage. Children are not thinkers and they cannot distinguish good from evil, it falls on the parents or caretakers as their ultimate responsibility to always guide them. According to the New Community Bible Catholic version ${ }^{2}$, “... Teach them (the words of God) to your children... Then your days and the days of your children will be multiplied in the land which the Lord promised on oath to give to your fathers" (conf. Deuteronomy 11:18-21). Again the book of proverbs states: "Listen, my son, to the teaching of your father, do not ignore your mother's instructions". Childhood is the period in which the personality is molded and the physical and mental faculties develop. It is therefore not out of place to say that the process of human development supplements the creation and mystery of the universe. The Psalmist says "children are an inheritance from the Lord, a reward for the fruit of the Body" (conf. Psalm 127:3). The prophet Malachy notes that Children are the "seed of the Lord" (conf. Malachi 2:15). In the Bible, Children are a blessing to the family. In fact the crown of old men are children's and the ornament of Children are their fathers.

In the New Testament, St. Paul says: the human body has many parts but the many parts make up only one body so it is with the body of Christ. From the Christian perspective social development is all about living successfully in the community. For Christians, community and relationship underpin life, just as the God head is relational - the Trinity. The Trinity models a perfect community of equals, united by a bond of love. For Christians, humans are created in God's image (conf. Genesis 1:27), therefore they are made for relationship. In the incarnation — God became human in Jesus—-which reminds Christians that God has a relationship with his creation that is to say "He is involved". According to St. Paul, The Church is described in relational term as the

\footnotetext{
${ }^{1}$ Retrieved from https://www.jewishangency.org/life-cycle/content/24224.

2 The New Community Bible. Ibadan, St. Paul Publications 2015.
} 
Body of Christ (Conf. 1 Corinthians 12:12). Regarding the social development from the Christian point of view, children social development is shown by their:

(1) Their use of a range of social skill in different context, including working and socializing with children from different religious, ethnic and socio-economical backgrounds.

(2) Their willingness to participate in a variety of communities and social settings, including by volunteering, cooperating well with others and being able to resolve conflicts effectively.

(3) Their acceptance and engagement with the fundamental African values of Democracy, the rule of law, individual liberty and mutual respect and tolerance of those with different faith, and belief; the children should be able to develop and demonstrate skills and attitudes that will allow them to participate fully and contribute positively to life in modern Africa.

On the other hand, morality is not just about good behaviour; it is also about shared values that are rooted in Christian belief. For Christians, all sinned and fall short of the glory of God (conf. Romans 3: 23) this means that all people do wrong things. The term "sin" is used here to mean both wrong things that hurt others as well hurting God. For the Catechism of the Catholic Church (CCC $)^{3}$ the heart of the Christian Gospel is the message that God dealt with sin through the death and resurrection of Christ Jesus (Catechism of the Catholic Church, No. 421). Christian also believes that the Holy Spirit works in believers to transform and renew them. Those beliefs shape the values that characterize their approach to moral development. God is love and it is God's act of love that brought salvation to the world. Christians look to the life and teaching of Jesus to help them understand what this means in practice; Jesus welcomed outcasts, showed compassion to the poor, healed the sick and gave his own life as a sacrifice. He taught his disciples that as forgiven people, they too should forgive others. Truth and integrity are also at the heart of the Christian message. Christ taught that he was "truth" (conf. John 14:6). Therefore honestly and truthfulness should be prominent in the church's policies and practice. Hence, children's moral development is shown by:

(1) Their ability to recognize the difference between right and wrong, readily apply this understanding in their own lives, recognize legal boundaries and, in so doing respect civil and criminal law.

(2) Their understanding of the consequence of their behaviour and actions.

(3) Their interest in investigating and offering reasoned views about moral and ethical issues, and being able to understand and appreciated the view points of others on these issues.

The parents therefore have great duties to guide children to have proper social and moral development. Pope Benedict XVI in Africae Munus (AM) says "children are gift of God to humanity and they must be the object of particular concern on the part of their families, the church, society and governments for they are a source of hope and renew life. God is particularly close to them and their lives are precious in the eyes, even when the circumstances seem difficult or impossible (Conf. Genesis17:17; 18:12; Matthew. 18: 10) (Africae Munus 65).

John Paul II in his Encyclical "Familiaris Consortio" (FC) says "concern for the child, even before birth, from the first moment of conception and then throughout the years of infancy and youth is the primary and fundamental test of the relationship of one human being to another (familiaris Consortio No. 26). It is this concern that prompted the writing of this paper, which aims at exposing the negative effects of social media on children's social and moral development. These children are the future of African continent. For in them we find the springtime of life, the anticipation of the future history of our present day Africa. In his other Encyclical letter,

\footnotetext{
3 The Catechism of the Catholic Church, Revised Ed. Paulines Publications Africa. 1994. Print.
} 
Evangelium Vitae (EV), John Paul II Further said "in the daily round of relations and choices, and through concrete actions and signs, parents should lead their children to authentic freedom, actualized in the sincere gift of self, and they should cultivate in them respect for others, a sense of justice, cordial openness, dialogue, generous service, solidarity and all the other values which help people to live life as a gift. In raising children, Christian parents must be concerned about their children's faith and help them to fulfill the vocation God has given them (Evangelium Vitae No.92). The area of social media is not excluded. Parents should be seriously involved; otherwise it will destroy all their efforts in trying to bring these Children to vibrant social and moral adults.

\section{Recommendations}

No one doubts that social media offers great and many opportunities for information gathering, entertainment and social interaction. It is a fact that many positive effects can be recorded from time spent online. However, parents should not ignore in any way at all sexual salutation and exposure identity treats, cyberbullying, online addiction which children are exposed to in the social media. This paper therefore encourages child educators and pediatrician to assist parents in child Internet access in the following way:

(1) Supervision of online activities: Experts should engage parents on the importance of supervising online activities. This they can do through active participation and communication. This will go a long way to remove remote monitoring with a "net-nanny" programme of monitoring in the absence of parents. Let parents be actively involved in the monitoring.

(2) Family online-use plan: There now is serious need for family-online use plan. This involves regular family meeting. Here the family is expected to discuss online topic and checks of privacy settings and also online profiles for inappropriate posts. It should be noted here that the emphasis is to be on citizenship and also on healthy behaviour. It should never be on punitive action except where it is seriously needed

(3) Useful advice on online use: Parents should be able to talk to their children on their online use, especially on the specific issues that today's online children face. Parents should not shy away from this. Experts should assist parents in this regard.

(4) Closing the gap between parents and children in the use of modern technologies at this point in time parents are encouraged to work hard on their own participation in the use of these technologies. This will go a long way to close the gap between them and the children in the use of the modern technologies. They need better education on this matter to solve the problem for the good of the children.

(5) Educators should be educated. It is obvious that one cannot give what one does not have. For this reason child pediatrician and child educators should always try to increase their own knowledge of digital technology. This will equip them with more educated frame of reference for the tools their parents/clients and families are using. Education is power.

(6) Provision of using information: Parents should be provided with useful information on challenging issues that children face online. They should also be seriously inform on reputable online resources such as tip on sexting, public education sites, and healthy children. Organised social media. When they know all these, they will be in better position to assist theses children who are searching for knowledge.

\section{Conclusion}

We appreciate the contribution of the social media in our present contemporary African society. The advent 
of social media sites have actually displayed multiple advertisements like banner ads, behaviour ads. These target people on the basis of their web-browsing behaviour and demographic-base ads that target people on the basis of a specific factor like age, gender, education and marital status. These influence both the buying tendencies of children and adolescents' and also their views of what is normal. Parents should also be meant to know of the behavioral ads as they are very common on social media sites and operates by gathering information on the person using a site. Children should be educated with precaution about online world and how to manage and avoid its hazards. The concern of parents is that the Internet affects the social and moral development of children. All hand should be on desk to assist these children to make use of these technologies.

\section{References}

Benedict XVI. (2011). Africae Munus, Paulines Publications Africa.

Ehmke, R. (2017). How using social media affects teenagers. Retrieved from Https://childmind.org/articles/how-using-social-media-affects-teenagers/16/3/2017

Ehmke, R. (2017). How using social media affects teenagers. Retrieved from Https://childmind.org/articles/how-using-social-media-affects-teenagers/

Ilogu Edumund. (1974). Christianity and Igbo Culture. New York Publishers, Ltd. IloguEdumund. (1974). Christianity and Igbo Culture. New York Publishers, Ltd.

Iris, V. C. (1979). Christian child development. San Francisco, Sydney: Harper and Rolv Publishers. Iris, V. C. (1979). Christian child development. San Francisco. Sydney: Harper and Rolv Publishers. John Paul II. (1982). Familiaris Consortio. Paulines Publication Africa John Paul II. (1995). Evangelium Vitae. Paulines Publications Africa.

Knowless, R. T., \& Mcleen, G. F. (1992). Psychological foundation of moral education and character development, an integral and theory of moral development. Washington: The Council for Research in Values and Philosophy.

Knowless, R. T., \& Mcleen, G. F. (1992). Psychological foundation of moral education and character development, an integral and theory of moral development. Washington: The Council for Research in Values and Philosophy.

Matthew, J. (2013). Media and morality. Retrieved from http://mediasmats.ca/blog/media-and-morality

Matthew, J. (2013). Media and morality. Retrieved from http://mediasmats.ca/blog/media-and-morality

Parrinder, G. (1961). West African Religion. London: Epwork Press.

Parrinder, G. (1961). West African religion. London: Epworth Press.

Pope John Paul II. (1982). Familiaris Consortio. Paulines Publication Africa.

Pope John Paul II. (1995). Evangelium Vitae. Paulines Publications Africa.

Ronald, D., \& Mariellen, W. (1975). Moral development, a guide to piaget and Kohlberg. New York: Paulist Press.

Ronald, D., \& Mariellen, W. (1975). Moral development, a guide to piaget and Kohlberg. New York: Paulist Press.

Unduyaundeye Florence. (2014). Impact of social media on children, Adolescents and families. Retrieved from Http://www.gifre.org

Unduyaundeye, F. (2014). Impact of social media on children, adolescents and families. Retrieved from Http://www.gifre.org

Unduyaundeye, Florence (2014). Impact of social media on children, Adolescents and families. Retrieved from Http://www.gifre.org 